\title{
Cotidiano no manguezal: coletores e estratégias de sobrevivência na natureza, Bacuriteua-Pará $(1975-1990)^{1}$
}

Ipojucan Campos ${ }^{2}$

\section{Introdução}

Este artigo liga o homem à natureza. Ou melhor, o homem atuando no ecossistema costeiro paraense é a sua chave. Com mais pormenor, o ensaio centraliza esforços na compreensão das dialéticas culturais, sociais, políticas, econômicas elaboradas pelos trabalhadores da natureza no bojo de um imenso espaço geográfico. Todavia, quem são os seus sujeitos? Onde "exatamente" atuam? E os documentos? Trata-se dos coletores de caranguejo de Bacuriteua, localidade administrada pela cidade de Bragança, localizada no Nordeste do Pará, distante 210 quilômetros de Belém, capital do estado. A respeito das fontes utilizadas, sấo depoimentos de trabalhadores que dedicaram boa parte da vida à coleta do crustáceo.

1 Este artigo é resultado do Projeto de Extensão aprovado para os anos de 2010/2011 e renovado para os de 2011/2012 na Pró-Reitoria de Extensão (PROEX) da Universidade Federal do Pará (UFPA). Dedico este artigo aos meus bolsistas Márcio Sousa da Silva, Alexandre de Brito Alves e Johny Sales da Silva.

2 Doutor em História Social pela Pontifícia Universidade Católica de São Paulo (PUC/SP). Professor Adjunto II da Universidade Federal do Pará (UFPA). Docente do programa de Pós-Graduação em Linguagens e Saberes da Universidade Federal do Pará (UFPA) e do de Ciências da Religião da Universidade do Estado do Pará (UEPA) 
Os campos metodológicos concentraram-se em quatro aspectos, quais sejam? Primeiro, entende-se que a prática da História Oral é uma criação tanto do entrevistado quanto do entrevistador. Isso acontece porque as ações dos historiadores, nesse caso, com suas perguntas, posição dos equipamentos e afã de elaborar o conhecimento histórico, corroboram para que se fabriquem histórias únicas, pois cada um dos sujeitos sociais desloca significados particulares da sua cultura e eles são compartilhados com todos os que participam da entrevista. (Portelli, 1997, p. 25-39) Com isso, jamais se deve perder de vista que os depoimentos são descrições únicas de vidas "passadas" ligadas ao "presente" e vice-versa e que igualmente elas se constroem e se reconstroem conforme o movimentar dos enredos no seio das lembranças consideradas mais expressivas pelo ser social, assim sendo são fragmentos de histórias que se apresentam como matérias-primas essenciais à elaboração do conhecimento histórico. Segundo, optou-se por não corrigir gramaticalmente as entrevistas, porque se considera que, como foram ditas, existam formas de linguagem, as quais expressam costumes, valores e hábitos. Terceiro, o texto está pautado em apenas três estratégias de sobrevivência (alimentação, instrumentos de trabalho e tempo de labuta), não representando a totalidade das táticas usadas no bojo do quadro geográfico em questáo. Quarto, deve-se deixar claro que as reflexóes a seguir possuem dívidas e são tributárias de outros estudos em torno da História Oral como, por exemplo, os de Alessandro Portelli, ${ }^{3}$ Maria Antonieta Antonacci, ${ }^{4}$ Yara Aun Khoury ${ }^{5}$. Mas acentua-se que as análises ora apresentadas procederam de e se apoiaram, na sua essência, em documentos que expressam - entre outros domínios - modos de vida daqueles que os constituíram: alguns coletores de caranguejo do ecossistema costeiro paraense moradores da localidade Bacuriteua.

Neste texto, com suas limitaçóes e dívidas, o fundamental será firmar a posição de que existem dinâmicas socioculturais (as quais se desdobram em va-

3 PORTELLI, Alessandro. O que faz a história oral diferente. In: PROJETO HISTÓRIA No 14: Cultura e representação. Revista do Programa de Estudos Pós-Graduados em História da Pontifícia Universidade Católica de São Paulo. São Paulo: EDUC, 1997, p. 25-39.

4 ANTONACCI, Maria Antonieta. Tradiçôes de oralidade, escritura e iconografia na literatura de folhetos: Nordeste do Brasil, 1890-1940. In: PROJETO HISTÓRIA No 22: História e oralidade. Revista de História da Pontifícia Universidade Católica de São Paulo. São Paulo: EDUC, 2001, p. 105-138.

5 KHOURY, Yara Aun. Narrativas orais na investigação da história social. In: PROJETO HISTÓRIA No 22: História e oralidade. Revista de História da Pontifícia Universidade Católica de São Paulo. São Paulo: EDUC, 2001, p. 79-103. 
riados aspectos, como político e econômico) forjadas pelos trabalhadores da natureza ${ }^{6}$ (coletores de caranguejo) do ecossistema costeiro. Tal teoria, para os desejos destas reflexóes, dizem respeito somente à ordem que as personagens dão frente às estratégias de sobrevivência e como elas ligam esse domínio com o tempo de trabalho no seio da natureza. Em conformidade com isso, o historiador lê que as posturas dessas pessoas não são alheias às vicissitudes geográficas do espaço de trabalho, porquanto há jogos conscientes no seio das suas representaçóes culturais, fato que fixa/encadeia exigências locais à formulação cotidiana de experiências. Essas lógicas são os fios da trama. Assim, o presente ensaio não aspira a mais do que isso, embora sejam absolutamente possíveis outras interpretaçóes. Ele está localizado na experiência de vida de diversos trabalhadores e, por conseguinte, nas concepçóes de como as pessoas manipulam o seu dia a dia. Então, é dessa maneira que se fortalece a teoria aqui apresentada e onde ela mais claramente se revela na presente reflexão. Destarte, parte-se de uma constatação absolutamente trivial: a de que o homem no manguezal elabora diversas histórias e elas se organizam em meio à infinidade de razóes (econômicas, culturais, sociais, politicas), as quais jamais podem ser desvinculadas, porquanto atuam transversalmente para forjar vidas e sociabilidades.

Por isso, é propósito do presente artigo concentrar-se nas interpretações dos costumes e hábitos socioculturais desenvolvidos pelos trabalhadores da natureza no seio do manguezal que circunda o espaço e a cronologia em questão. Assim sendo, é mister jamais menosprezar a concepção de que o historiador lerá e escutará vozes do "presente" que se entrelaçam com histórias do "passado", pois se compreende que este sempre chega naquele redito, refeito, reelaborado. Deve-se notar que há interrelaçóes constantes entre o momento do fato e o tempo em que a narrativa se realiza posto que o primeiro aparecerá reconduzido ao presente conforme as necessidades históricas do narrador. Com efeito, os depoentes (como em qualquer documento) apresentarão recortes em suas memórias acerca de como são repousadas a ordem e a disciplina de trabalho no bojo do ecossistema costeiro. Todavia, haja o que houver, nunca se deve duvidar de que a partir das

6 Trabalhadores da natureza foi uma categoria utilizada em outro trabalho para explicar a importância dos homens e mulheres "comuns" na economia da cidade de Bragança. Ver: CAMPOS, Ipojucan Dias. História e natureza: memórias, sobrevivências, famílias e relaçôes de poder no manguezal (Bragança - PA, 1980 a 1990). Artigo aprovado pela Revista Margens (UFPA), 2010. 
narrativas dos trabalhadores, neste caso, as dos coletores de caranguejo, é viável elaborar conhecimento histórico e não é difícil reconhecer isso, uma vez que as personagens a seguir ressignificam - a cada momento das suas exposiçóes - experiências frente aos domínios de sobrevivência no seio do seu local de trabalho. O historiador compreende que esse elo se forma porque há ligaçôes inquebrantáveis entre o "ser social e a consciência social", ou seja, nas narrativas nota-se ser indissociável a noção de que há unidades entre trabalhadores e o que o ecossistema representa para eles. Os diversos Pedros, Andrés, Josés, Miguéis claramente descortinam consciências sociais (como as das possibilidades de sobrevivência) referentes às necessidades das suas vidas. Ao se considerar tal proposição minimamente coerente, fica fácil, crê-se, compreender o objeto de análise contido neste texto e, assim dito, interpretar as razóes de como o conhecimento histórico pode ser elaborado.

Sem essa certeza, o historiador não pode agir. E sem ela, "qualquer" sujeito social pode colocar a História Oral de ponta a cabeça, sacudi-la e, finalmente, chegar ao absurdo de dizer que nada nela há ou que náo se pode, a partir dela, forjar conhecimento histórico. Lógico, não se alimentará essa ilusão grosseira, porque se compreende que tal escaramuça a historiografia já tenha superado, mas nunca é devaneio acentuar a referida proposição.

Assim sendo, seguem-se as análises do que se cunhou de dinâmicas socioculturais na natureza.

\section{Dinâmicas socioculturais}

Como os inúmeros Pedros, Andrés, Josés, Miguéis, Manoéis se organizam no seio do ecossistema costeiro quando o assunto se concentra nas açôes e práticas manipuladas por eles e destinadas a "vencer" as dificuldades naturais que o quadro geográfico apresenta?

Diante dessa questão, é de suma importância compreender que esses trabalhadores elaboram e reelaboram domínios socioculturais que atuam transversalmente e influenciam sociabilidades e solidariedades. Em outras

7 Esses termos o historiador tomou emprestado de Edward Palmer Thompson. Ver: THOMPSON, Edward. A miséria da teoria ou um planetário de erros. S/C: Swing e Ludistas Sensuais, 2009. 
palavras, por meio da experiência, montam estratégias que lhes possibilitam estabelecer relaçóes com o meio ambiente e estas proporcionam inevitavelmente vínculos de respeito entre o homem e o seu local de trabalho. Assim, as suas dinâmicas socioculturais devem ser interpretadas como elos da corrente que ligam, inexoravelmente, por exemplo, hábitos alimentares ao tempo de labuta no seio do ecossistema, destarte alimentos, disciplina e regime de trabalho sejam aspectos absolutamente ligados e funcionem de forma indissociável na vida das pessoas em pauta. É por essa razão que o manguezal nunca pode ser apreendido como espaço estritamente da natureza. Ele é para além disso, uma grande via que consegue criar corredores de solidariedade e de união entre as personagens em questão. É um solo fértil, de onde inumeráveis pessoas "coletam" a sobrevivência, ou seja, exploram comercialmente o caranguejo e desempenham papel essencial na economia do lugarejo e na da sede do município, Bragança. Em conformidade com isso, esse espaço da natureza é um território, uma zona de contato e de circulação entre o ser humano e o meio ambiente, uma vez que, quando bem se observa, encontra-se sentido entre as árvores como o mangue preto (Avicenia), o mangue branco (Lagunclaria Racemosa), o mangue vermelho (Rizophora Mangle) e as necessidades econômicas, políticas, culturais e sociais das personagens em análise. Dão-se as mãos, dessa maneira, os homens e a natureza. Essa união proporciona ler surpreendente variedade de tipos e formas.

Mas, como as estratégias de sobrevivência revelam-se no bojo da natureza? O colaborador Miguel Pinheiro da Silva, 67 anos e 20 de experiência como coletor de caranguejo, expressou esses campos da maneira seguinte:

(...) pescava 8 quilo de peixe, levava linha e ainda trazia peixe pra casa. Levava a farinha, levava a despesa como o tabaco. A droga náo é comigo. Bragalhão, bagre a gente pegava muito e mais a farinha, das 9 às 2 hora era o tempo, o meu tempo do trabalho no mangue. O peixe pescado era cozido. Nois tinha panela, prato, colher (...). A vida no mangual é difícil. É perigosa, uma furada no pé é sempre grave porque como sair? Aí entrou o sapato. A luva. A calça comprida. A camisa de mangas compridas. Quando isso acontece apenas com a ajuda dos colegas de profissão. Isso sempre acontece porque existe muito pau enterrado na lama e nós náo vê. Se quando cai de um pau pode quebrar uma costela, a perna e o braço. Quando isso acontece e não é difícil acontecer os amigo é a solução. Caso 
contrário, é difícil, mas já aconteceu o moço fica lá, perdido, sem ter o que fazer e aí só Deus (...).

Eis um depoimento que liga as bases deste artigo. Para o Senhor Miguel, as táticas de sobrevivência no campo alimentar eram bem definidas antes de se adentrar na natureza. Tal domínio organizava-se em diversos espaços sociais, como no próprio lar, no comércio da cidade de Bragança, no ponto de saída para a labuta, nas pontes da estrada que cortam o ecossistema. Em sua narrativa, observam-se as dinâmicas socioculturais que o velho trabalhador estabelece com as exigências do quadro geográfico. Ao rememorar o passado, a linha de pesca é significada como instrumento essencial à sobrevivência, pois possibilita refeição farta (bragalhão, bagre), não somente para o consumo no seio do manguezal, mas também direcionada à família, porquanto o que resta as mulheres e os filhos consomem. A farinha de mandioca é explicada como item fundamental, leva-se de casa ou se compra nas inúmeras vendas que se formaram nos pontos de saída dos trabalhadores da natureza para o bojo do ecossistema, ou seja, nas cabeceiras das pontes.

Os homens geralmente alimentavam-se antes de adentrar no manguezal, e a dieta concentra-se, basicamente, em peixe, embutidos e farinha. $\mathrm{O}$ local onde se nutrem varia, podendo ser no lugar de onde as canoas saem (das cabeceiras das pontes) ou nos diversos ranchos construídos no interior do manguezal para servir de pontos de apoio aos trabalhadores. O rancho é lugar importante para esses sujeitos sociais, porque nele, além de outras táticas, preparam-se refeiçóes e, sobre esse aspecto, Seu Miguel o ligou - muito tranquilamente - às estratégias alimentícias, isto é, afirmou possuir utensílios domésticos como "panelas, pratos, colheres". Sobre a dieta, obviamente, as combinaçóes mudam conforme as necessidades impostas, porém, nos depoimentos, a farinha é sempre apresentada como item insubstituível; ela figura em todas as situaçóes, pois o alimento é básico, seja quando pensado como aspecto cultural, seja nos limites financeiros, em virtude do seu acessível preço. Destarte, é temeroso e imprudente adentrar na natureza desprevenido de mínimas bases alimentares nem que seja um chibé (farinha com água) os homens que buscam a sobrevivência econômica no ecossistema fazem como refeição. Jamais se deve esquecer de os coletores suportam longas jornadas de trabalho, as quais - segundo o depoimento em questão - prolongam-se das 9 às 14 horas, ou seja, cerca de cinco horas de pesado esforço físico. 
Veja-se quanto tempo e esforço - em meio a perigos - são despendidos para se forjar a sobrevivência de si e da família. Cinco horas de trabalho diariamente, vencendo as árvores, os troncos, as raízes, os sedimentos (lama), as possíveis quedas e diversas outras imposiçóes do quadro geográfico. Mas "vencer" esses obstáculos significa, na mentalidade dos inúmeros coletores, a possibilidade de uma vida melhor. Deve-se, também, observar que, se por um lado, a natureza é lugar de dificuldades e riscos, por outro, os trabalhadores a concebem como probabilidade de mudança econômica, uma vez que, sendo o ecossistema uma "mina de caranguejo que nunca vai se acabar", entendem que podem ter dinheiro todos os dias. Aliás, o ecossistema é vislumbrado dessa forma; não como lugar para se conseguir dinheiro fácil, é evidente, mas, sim, como lugar onde, possuindo disposição, há dinheiro para as provisóes e outras necessidades. É através das narrativas dessas vivências pessoais que se compreende ser viável a elaboração do conhecimento histórico. Dito de outra maneira, o historiador vislumbra claramente em quais teias as dinâmicas de sobrevivência se concentram, isto é, os perigos que a natureza impóe forçam os coletores a buscarem soluçóes. Por exemplo, ao notarem que um acidente (como uma furada no pé) transformara-se em evento de difícil solução, eles passaram a adentrar calçados no ecossistema costeiro. Ligam imposiçóes naturais às das necessidades de sobrevivência. A esse respeito, precisa Seu Miguel, os significados das calças e camisas de mangas compridas e das luvas indicam um mesmo sentido: $o$ da proteçáo do trabalhador no seio da natureza. Aqui se apresentam, claramente, os elos entre o ser social e a consciência social, campos tão bem interpretados por Edward Thompson. (Thompson, 2009, p. 139)

Nota-se como esses homens constroem história e, um ponto importante a se acentuar, é o da solidariedade, porquanto mesmo "bastante" protegidos, não conseguem se livrar totalmente dos riscos de acidentes. Como expressa o depoente, contratempos no seio do manguezal acontecem e não são incomuns, todavia se o fato ocorre, relaçóes interpessoais entram em ação, pois elas têm o poder de movimentar e de deslocar amizades, valores e padróes. Vislumbra-se, assim, como e em quais condiçóes essas pessoas fazem História. Esta é articulada - logicamente - na contradição e na rivalidade de quem mais coleta o crustáceo, porquanto seria demasiadamente ingênuo lê-la fora desses ambientes, entretanto, é importante observar que também se realiza nos campos da convergência, da solidariedade, dos interesses comuns. 
É nesses espaços que o historiador reforça o que se vem categorizando como dinâmicas socioculturais na natureza, uma vez que as múltiplas linguagens produzidas ordenam experiências únicas, as quais apresentam modos de vida, anseios e desejos individuais e de grupo. Com efeito, há, nos registros, dimensóes que se manifestam por meio de bricolagens entre vidas e exigências da natureza. Tais ligaçóes permitem movimentar interesses e sentidos das necessidades daqueles que sobrevivem do manguezal. Em conformidade com essa proposição, enfatize-se que as formas de linguagem em pauta articulam intermediaçóes entre os rigores apresentados pelo quadro geográfico e as essencialidades contidas.

É mister expressar que, do ecossistema costeiro, o coletor de caranguejo, com suas afirmaçóes consistentes/inteligíveis de tudo aquilo que o caracteriza, também apresenta narrativas da sua alma, do seu espírito, das suas crenças, do seu cotidiano, das suas experiências, das suas conquistas, das suas desilusóes, dos seus perigos. A mentalidade dos diversos sujeitos sociais em questão concentra-se nessas pilastras, ou seja, para eles, a natureza não é somente lugar onde se vive e se reproduz o crustáceo táo procurado e preciso à vida, ela é e significa o local em que se manifestam as suas próprias vidas: pública e privada, intima e secreta, econômica, social, política e cultural.

A respeito do dia a dia dos trabalhadores, com as suas estratégias de sobrevivência, dieta alimentar e regime de trabalho revelam-se em domínios importantes e, acerca destes, o Senhor Benedito Faustino da Silva, 47 anos e 21 de experiência, é categórico. Leia-se o excerto:

Muitas as vezes a gente leva feito, mas muitas as vezes a gente não leva, a gente compra, a gente compra lá no porto lá aonde a gente pega a canoa, compra o peixe cozido come pra poder ir, quando sai esta comida a gente entra mais tarde no mangal, a gente diz assim: eu vou depois que comer, isso também é por matizada né, tem muitas das vezes que a gente fica lá na ponte grande aonde a gente tira, passa a noite aí quando é umas 4 horas da madrugada sai, que pra ir cedinho, quando a gente faz isso a gente tira mais ainda né, porque tem mais espaço a gente vai mais longe é tem mais tempo, pra quem já tá acostumado é divertido, é sacrificoso mas é divertido.

As táticas na natureza são surpreendentes e inúmeras. No campo alimentar, Seu Faustino apresenta outras formas de enfrentar este mundo. Nota-se, também, o quanto as pessoas ressignificam o ecossistema, ou seja, o 
transformam em espaço absolutamente movimentado, onde jamais se observam cristalizaçôes. Não é a dieta, efetivamente, mas são, sim, as especificidades para se conseguir alimentos que mudam de trabalhador para trabalhador. Tal fato faz o historiador pensar que o importante é interiorizar-se no manguezal e "vencê-lo" dia após dia. Quanto à dieta, leva-se ou compra-se. Em seu depoimento, Benedito Faustino da Silva indica essas duas possibilidades para se adentrar alimentado na natureza. Ao rememorar o árduo trabalho, sugere ser trivial comer algo antes de enfrentá-la. Previamente preparado no lar pelas esposas e filhas mais velhas, ou comprado já pronto nas cabeceiras das pontes de onde se sai para enfrentar os perigos do manguezal, a dieta desses trabalhadores pouco muda, pois, ao se compararem as suas narrativas notou-se a presença constante do peixe, da farinha, da farofa, do chibé, dos embutidos.

A dieta alimentar é um bom caminho para se compreender o manguezal, com os seus homens que nele penetram resolutamente. Nesse ambiente bastante misturado, de onde pululam pessoas, enfrentá-lo com apenas farinha de mandioca no estômago não é suficiente, mas esta se transforma em essencial quando apenas dela se dispóe. Findas as manobras alimentícias, as quais são múltiplas, jamais agindo todas simultaneamente e da mesma maneira, os trabalhadores da natureza sentem-se mais seguros para se defrontar com o mundo natural, porquanto eles possuem ideias complexas e não sumárias desses campos (ecossistema costeiro) que são tão férteis, os quais, com suas cadeias naturais bem notáveis, traçam significativamente em linhas inteligíveis os seus quadros utilitários à sociedade que servem. Nessa ordem das coisas, homem, História e natureza são indissociáveis. Prezado leitor, se assim também compreenderes, aqui é elementar localizar a concepção de tempo de labuta, ou seja, os homens que de forma sacrificante lutam para suster a família não começam as suas jornadas quando adentram na natureza, as pressóes da jornada iniciam-se bem antes. No que respeita essa lógica, o Senhor Faustino precisa que acordar às quatro horas da madrugada é trivial para se coletar quantidade razoável de caranguejos, porque haverá mais tempo (nota-se a construção deste), e também em virtude de o coletor ir mais distante no interior do manguezal, isto é, ele consegue explorar lugar ainda "pouco" visitado ou a que nenhum trabalhador tenha, naquele dia, chegado. Eis as estratégias forjadas quando o assunto é "vencer" as vicissitudes impostas por um espaço geográfico que exige precauçóes e maneiras distintas de comu- 
nicação. Então, está-se lidando com material bastante resistente da prática do historiador (o da experiência individual das personagens em pauta), ou melhor, exatamente com a dinâmica sociocultural das pessoas que se envolvem na difícil faina. É nessa dimensão, como disse Edward Thompson, que inteligivelmente se estabelece a proposição de que todo e qualquer momento histórico deve ser interpretado como uma intermediação, um resultado de aspectos históricos anteriores. (Thompson, 2009, p. 69).

A se considerar as interpretaçóes de Edward Thompson, é possível pensar os elos entre passado e presente elaborados pelos trabalhadores em análise. Assim, as vidas que se entrelaçam no seio do ecossistema costeiro podem ser interpretadas como elementos humanos que se clarificam através de aspiraçóes, desejos, necessidades, interesses, apreensóes vividas e interpretadas e que, finalmente, mostram-se por meio do argumento da dinâmica sociocultural ora apresentado.

Nesse sentido, vemos como pensa o depoente em pauta a respeito do cotidiano no manguezal. Ele fala de maneira absolutamente clara, acompanhemos:

É eu acho assim, das várias experiências que a gente tem, muito tempo, né, conhecimento que a gente tem dos colegas que trabalham nessa vida, a gente vai alegre, vai conversando, leva um duelozinho, vai contando aquelas prosas é lá no igarapé a gente seca, si que a gente vai merendar, é, remendar a luva é remendar sapato é fica tudo só pro má hora lá dentro mangal é aí a gente se fica nu: tira a roupa, a roupa da gente que a gente vai limpa, bota a do mangal que é. Hoje a gente tá trabalhando de calça comprida, camisa manga comprida, sapato e a luva, aí a gente tira a roupa limpa vesti a suja a do mangal é calça, o sapato, bota a luva no braço é aí que a gente vai tirar caranguejo, tens uns cigarros, é 95\% dos tirador de caranguejo tudo fuma um porroncão, a diária de um tirador de caranguejo é 4 cigarros grandes, ele faz aquele porroncáo, ele fumando e vai tirar caranguejo. Às vezes ele sai da canoa 10 horas do dia e só vai retornar só 4 horas da tarde direto lá, aí, se ele tiver que tomar água ele toma na canoa, se tiver que comer alguma coisa ele come na canoa, tudo que ele tiver que fazer ele faz na canoa (...).

O depoimento é transversal. Variados aspectos da vida no seio do manguezal são apontados. Inúmeras dificuldades também. A alegria da conversa 
nos barcos que atravessam os rios e braços dos igarapés, a bebida alcoólica (representada no duelozinho), o conserto das vestimentas próprias à coleta (luvas, calças compridas, camisa também de mangas compridas e sapatos), a porronca (cigarro grande, de palha e massudo) são alguns aspectos do dia a dia no interior do ecossistema. Deve-se afirmar que o seu uso faz também parte da ordem de sobrevivência no seio da natureza, visto que variados homens dizem que a utilizam não em razão do vício, e sim para afugentar carapanâs (pernilongos), mosquitos, mucuins, mutucas que habitam a geografia em análise. $\mathrm{O}$ excerto transpassa pelo centro deste ensaio: $o$ da organização de estratégias de sobrevivência das personagens em pauta. Sobre o tempo de trabalho, é essencial o historiador fazer uma observação. No primeiro fragmento, esse depoente anota que muitas vezes os coletores começam a se organizar para o trabalho por volta das quatro horas da madrugada; já no segundo, Seu Faustino expressa que as fainas da coleta iniciam-se às dez horas da manhã e se estendem até as dezesseis. Inexiste contradição nas informaçôes, pois, de uma forma ou de outra, o colaborador vislumbra que a jornada é longa e que náo começa quando o homem chega ao local da coleta. Desta feita, náo despreza as horas precedentes utilizadas para se chegar, por exemplo, aos pontos mais propícios à captura do crustáceo. Nessas condiçóes, e se o leitor considerar coerente, o resultado dessa equação é o somatório dos dois tempos e, por assim dizer, há determinados homens que labutam cerca de doze horas para conseguir prover a família, vencendo caminhos internos aspérrimos, longos e difíceis.

Ao se interpretar esses e outros dados, deve-se dizer a respeito da dinâmica de trabalho no seio do manguezal que a interpretaçáo do que vem a ser tempo de labuta não é a mesma para todos os trabalhadores. Para o Senhor Miguel, a propósito, a sua conta não inicia de madrugada, quando se levanta da rede ou da cama, mas, sim, a partir do momento em que adentra no ecossistema costeiro. Por outro lado, como se notou, o colaborador Benedito Faustino da Silva diz ser importante considerar outra adição, ou seja, a jornada inicia na madrugada, às quatro horas, quando se levanta para se arrumar e se dirigir ao local de trabalho. Apreende-se a dinâmica que o espaço estudado proporciona. Sáo essas características que desfazem qualquer indicativo de estruturalismo frente às lógicas históricas que se vêm analisando. Estas no quadro geográfico em pauta, conseguem promover interpretaçóes várias, as quais são construídas e reconstruídas conforme as 
necessidades impostas pelo lugar em que se atua e, logicamente, de acordo com a maneira como as pessoas refletem esse mesmo lugar no seio do tempo histórico vivido. É nesse sentido que o pesquisador compreende a História enquanto processos construídos, forjados, elaborados pelos homens, que a constituem de forma complexa, contraditória, ambígua. Isso acontece porque o que efetivamente se interpretam são mentalidades (aqui se emprega no sentido de como as pessoas pensam as dinâmicas da vida) e elas mudam - entende-se - segundo as conveniências, necessidades, interesses, pressóes sociais, políticas e econômicas de cada personagem social. No que respeita a essa dimensão, os diversos homens da natureza que se vêm interpretando são agentes que sempre estiveram próximos às proposiçóes aqui expostas, visto que, em deslocamentos específicos e constantes, fabricam modos de vida, de viver e de se organizar de acordo com o que as suas experiências proporcionam no bojo do ecossistema costeiro paraense.

O manguezal possui sentidos sociais, repita-se. Veja-se que a construção do lugar quem faz são os homens, e eles o elaboram conforme seus gostos, necessidades e exigências do momento; então, vale deixar claro que aos propósitos deste artigo o que importa são as açóes dos homens na natureza, não é nada além dessa aspiraçáo. Disto isso, quando o assunto é dieta e tempo de labuta, os trabalhadores formulam estratégias próprias para conseguir o maior número possível de cambadas (uma cambada é um conjunto de 14 caranguejos), ou seja, sair para o interior do manguezal "bem forrado" significa permanecer por mais horas no bojo do ecossistema costeiro e, por conseguinte, alcançar números mais expressivos do crustáceo para comercialização. Apreende-se o quanto na coleta há lógicas sendo utilizadas. A alimentação, o tempo de trabalho, as vestimentas usadas para a captura do crustáceo são aspectos indissociáveis dos homens que pululam no meio ambiente em pauta. Doze horas ou qualquer outro tempo de labuta expressa esforço executado para suster conjunto importante de pessoas do seio familiar; alonga-se o tempo de serviço quando se pensa nesse aspecto, isto é, a família numerosa, por exemplo, "pressiona" o trabalhador a estender a faina para além.

Assim sendo, afirma-se que a presente reflexão concentra-se em intercâmbios contínuos entre homem e natureza, mas aquele sendo a única

8 Significa ingerir algum alimento (farinha, peixe, conserva). Não necessariamente manter-se nutrido. 
personagem e, por isso, a central, pois atua nesta. Reforça-se também a ideia de que as suas histórias não são notas separadas, mas, sim revelam unidades que, naturalmente, envolvem as mais diversas pessoas, como as que compóem a família. A se considerar essa proposição razoável, os trabalhadores do manguezal estabelecem entre si coerente cultura política para enfrentar as vicissitudes do lugar e, dessa forma, elaboram ordens e estratégias que lhes proporcionam a sobrevivência cotidiana fora e nos interstícios daquele quadro geográfico. Com isso, e sendo mais inteligível a explicação histórica, deseja-se fazer compreender que há lógicas para se "vencer" as forças impostas pelo ecossistema. Exemplar nesse sentido é o que expóe o colaborador Benedito Faustino da Silva que, ao narrar as suas experiências, apresenta, claramente, como as personagens sociais forjam um dado cotidiano que é elaborado e reelaborado dia a dia, ou seja, as dinâmicas socioculturais concentram-se no seu fazer-se, porque estes demonstram significativas ordens nos espaços da disciplina de trabalho desenvolvidas no seio do ecossistema costeiro.

$\mathrm{O}$ autor deste artigo compreende bem esses campos, uma vez que as diversas pessoas que o adentram e o exploram para buscar a sobrevivência não o fazem aleatoriamente. Nesse sentido, está-se pensando nas táticas fabricadas pelos trabalhadores, isto é, nas calças e nas camisas de mangas compridas, nos sapatos e nas luvas. Essas ferramentas devem ser compreendidas como lógicas que forjam a conquista do quadro geográfico apresentado aos homens. É nessas trincheiras que se vislumbra como a História é elaborada. Esta, por ser própria dos homens, jamais pode ser interpretada como cristalização que se localiza em espaço e tempo determinado. As narrativas utilizadas demonstram, inteligivelmente, esses domínios, isto é, um passeio que liga de maneira inquebrantável passado e presente. Com efeito, ensina o depoente Benedito Faustino da Silva que as histórias dos homens da geografia estudada são pontilhadas, complexas, multifacetadas. Isso acontece porque as pessoas não se dissociam dos seus interesses, desejos e afẫs, ou melhor, quando as personagens em questão atuam em seu local de trabalho, ocorre que estas pontuam códigos de uso do espaço em que se relacionam inventando e reinventando o que se vem, aqui, categorizando como dinâmicas socioculturais na natureza.

Os homens, ao se forjarem socialmente, conseguem desconstruir polaridades como as da cultura erudita e popular, assim, "simples" atos no seio do ecossistema, como o de se vestir com as roupas de trabalho, transforma-se 
em aspecto essencial às pretensóes das pessoas que de lá tiram o sustento, ou seja, o cotidiano apresenta a todos como se pode e se deve viver e sobreviver do lugar. A experiência (estratégia) é essencial no bojo do ecossistema, tanto que o colaborador em pauta afirma ser trivial a porronca e a aguardente, além de uma vestimenta adequada para se enfrentar os perigos e dificuldades do quadro geográfico. Estas estão diretamente ligadas ao regime de trabalho e, como bem expressa o depoente em questão, "às vezes ele sai da canoa 10 horas do dia e só vai retornar só 4 horas da tarde direto lá, aí, se ele tiver que tomar água ele toma na canoa, se tiver que comer alguma coisa ele come na canoa, tudo que ele tiver que fazer ele faz na canoa (...)". ${ }^{9}$ É mister compreender que o(s) depoente(s) consegue $(\mathrm{m})$ pontuar uma infinidade de procedências no que concerne à utilização de códigos adequados à sobrevivência, assim sendo - aos propósitos deste artigo -, é razoável nunca negligenciar que o conhecimento histórico elabora-se essencialmente da experiência, do deslocamento histórico das personagens sociais em pauta, visto que os significados sociais, culturais, políticos e econômicos que exprimem maneiras de vida, de lutas, de posicionamentos, de organização são os que, consequentemente, fabricam as suas dinâmicas socioculturais. Em conformidade com essa proposição, vêm à tona evidências da complexidade da vida dessas pessoas que, ao mesmo tempo, deixam entrever o quanto o exercício cotidiano dos homens articulam linguagens que se concentram não apenas na elaboração econômica, mas também nas formas de relaçóes interpessoais que envolvem crenças, costumes, valores, ou melhor, convivências localizadas nos espaços socioculturais da vida cotidiana dos protagonistas em análise.

Claro se apresenta que os argumentos aqui definidos se distanciam do estruturalismo. Os sujeitos em pauta náo suportariam se enxergar ou ser localizados em espaço tão reduzido. Logo eles que possuem imenso lugar de trabalho e neste formam convivências múltiplas. Isso seria, inevitavelmente, contraproducente e conservador. Os trabalhadores da natureza constroem campos socioculturais deslocando cotidianamente experiências, e tal movimentar engloba, necessariamente, diversos agentes sociais (amigos de labuta, familiares, conhecidos). Há, então, um domínio dialógico nos enredos das histórias apresentadas e é por essa razão que os diversos Andrés, Miguéis,

9 Entrevista concedida pelo Senhor Benedito Faustino da Silva, 47 anos. Bacuriteua, 24 de maio de 2010. 
Manoéis do ecossistema costeiro nunca devem ser observados como constituidores de um único lugar; seria ingênuo expô-los dessa forma.

Ao se referir a alguns sentidos úteis para se forjar a vida, o depoente André Tavares da Gama, 57 anos e 33 de experiência no manguezal, reforça as suposiçóes apresentadas de que o quadro geográfico em análise exige disciplina, e ele o apresenta de forma absolutamente inteligível quando se lembra das estratégias usadas para vencer longas jornadas de trabalho. Leia-se um trecho das suas declaraçôes:

É leva todos nós, levava a gente chama merenda, né, aí a gente levava a merenda da gente pra poder forrar a barriga antes de entrar no brejo pra tá forrado, a gente come pra poder entrar lá dentro. Nós levava pronto já, se acordava cedo fazia e levava, quando não dava tempo e quando também a gente não tinha a gente não levava, é, agente levava só a farinha e molhava um chibezinho agente corria dentro. Agente pegava o caranguejo e fazia assim, imbora fazer avuado, aí pegava uns caranguejos fazia um fogo assava e nós comia, depois que se acabava de comer nós se aprontava e ia, vestia a calça, calçava o sapato, camisa, vestia a luva e ganhava o brejo, o vizinho só era quando agente tava na beira da estrada, depois que caísse lá dentro do mangal todo mundo ia se virar pra tirar a produção, era um pra cá, outro pra cular, era muito cuidado pra não se perder, né, porque o manguezal já sabe como é central, né a gente tem cuidado. Olha, existe perigos de não pegar uma furada, né, e também ter cuidado pra trabalhar só porque tem um bicho invisível aí, o Ataíde que chamam, né, agente tem que ter cuidado tem a Curupira, a gente também tem que não andar muito no centro da raiz, não escapulir porque se escapulir vai quebrar um braço, uma perna, bate uma costela.

Afirma-se que há domínios dialógicos nas experiências dos trabalhadores do manguezal. Nessa linha de raciocínio, e para além do escopo dessa constatação, deve-se observar como esta se inter-relaciona de modo a formar aspectos importantes e necessários à construção da sobrevivência, uma vez que se deve seguir disciplina no bojo do cotidiano que se enfrenta recorrentemente. Nota-se como e quanto as pessoas elaboram e reelaboram, compartilham e delimitam relaçóes de sobrevivência, as quais se localizam nas mais variadas concepçóes de se forjar a vida; eles (os coletores) compreendem esse paradigma, veem e sentem essa dinâmica. Assim, vislumbram 
as suas histórias como deslocamentos que jamais se localizam apenas no seio do ecossistema, mas também entre a família, os amigos, a sociedade. Esse processo múltiplo, construído por esses personagens sociais, inteligivelmente se apresenta em suas narrativas quando, por exemplo, argumentam a respeito da alimentação bem como sobre as maneiras arquitetadas para se escapar dos perigos que a natureza insiste em apresentar a eles. É por essa razão que a tríade cotidiano, natureza e disciplina se mostra indissolúvel. Ela articula projetos, desejos, costumes e necessidades que devem ser organizados e levados a sério em um ambiente que exige cuidado. Por isso, a necessidade da alimentação antes de adentrar, bem como das vestimentas adequadas para que sejam evitados acidentes apresentam-se como instrumentos importantes para suas aspiraçóes.

Nesses momentos constata-se a impossibilidade de se utilizar de forma fechada as representaçóes construídas pelos sujeitos em suas práticas cotidianas, pois a consciência social organiza-se no sentido da pluralidade, e ela se forma quando o historiador interpreta grupos e também um único sujeito. A respeito dessa vertente, o depoente André Tavares da Gama é absolutamente claro. Mas, dito por meio de outra perspectiva, ao se considerar que a consciência social das personagens em pauta é multifacetada, qualquer tentativa aplainadora desse domínio colocaria ricos depoimentos no interior de explicaçóes genéricas e estruturalistas e isso, repita-se, seria demasiadamente deletério para as práticas e as experiências forjadas pelos trabalhadores em questão. É na negação do aplainamento, do estruturalismo, da redoma explicativa que se fortalecem os argumentos apresentados. Aliás, negar e compreender que inexistem fins objetivos é desafio que se apresenta ao oficio do historiador, uma vez que o texto sempre deve se apresentar àquele que ler - como espaço a para outras possibilidades e avaliaçóes. Que essa dimensão seja seguida os coletores de caranguejos exigem, não apenas no seio de sua prática, mas daquele que os leem. Por essa razão é complexo o exercício de adentrar na experiência das pessoas em análise. Localizar em quais lugares incorporam e recusam representaçóes socioculturais não se caracteriza atividade simples.

Procurou-se captar, das expressóes dos depoimentos, modos de ser e de viver, estratégias de sobrevivências, aspirações, desejos, solidariedades, sociabilidades, sonhos, expectativas, costumes e valores que as pessoas interpretadas ordenam em seu cotidiano frente à dura geografia do local de 
trabalho. A esse respeito, importante artigo, "Tradições de oralidade, escritura e iconografia na literatura de folhetos", articula que, se o conhecimento histórico emana de qualquer experiência e se ele se concentra em costumes, tradiçôes, valores, atitudes históricas, então, o "mesmo" conhecimento histórico jamais deve negligenciar grupos portadores de tradiçôes orais. (Antonacci, 2001, p. 116). Em direção a essas observaçôes da historiadora, notam-se, nos diversos depoimentos coletados no Nordeste paraense, as inúmeras formas de sobrevivência. Exemplo disso está ao tempo em que os colaboradores refletem que grande perigo no bojo do ecossistema costeiro é o de levar uma furada no pé e o de escapulir de uma raiz e quebrar uma costela ou braço. Quando assim pensam e são interpretados, compreende-se ser nesses instantes que os colaboradores argumentam que a natureza exige táticas adequadas para que os deslocamentos dos homens sejam mais amistosos na geografia a se enfrentar.

A teoria da existência de dinâmicas socioculturais firma-se a cada leitura interpretativa dos documentos, e é reforçada quando se pensam as estratégias (que não são esparsas nem simplórias) construídas e reconstruídas, lidas e relidas pelos atores em análise. Elas sempre estão interligadas e transpassam a vida pessoal e, por conseguinte, as imposiçóes naturais do ecossistema costeiro. Esses aspectos tomam maior musculatura por meio dos depoimentos que versam sobre a dieta, e a esse respeito o Senhor Reinaldo Cunha, 36 anos e 18 de labuta, afirmou:

É que nem eu tava lhe falando ainda agora antes de ser gravado, eu tava falando que quando a gente tem a gente leva, né, quando a gente náo tem a gente não leva, a gente passa mal sobre isso aí, porque as vezes a gente vai pro manguezal, aí se si apronta lá pra cair no manguezal, e leva farinha toma só um chibezinho pra sair a tarde, é sobre isso aí que é o maltrato da gente, porque as vezes a gente não tem e quem tem náo vai levar pra gente lá, é assim o maltrato é esse aí. Tem muito tirador de caranguejo mermo, que ainda diz que trabalha no mangal e diz: eu não sinto nadinha no mangal, o cara ainda tem coragem de dizer que náo senti nadinha, eu trabalho no mangal quando de tarde eu me sinto todo dolorido. É porque o mangal é serviço pesado, já pensou cê tá todo dia aí na lama aí, de manhã cedo até a tarde atolado tirando caranguejo? Como dizer que de tarde não tá sentindo nadinha? Ele não é Cristáo não, porque o serviço é duro. 
O trabalhador precisa muito bem as dificuldades do dia a dia na natureza e dado importante é quando percebe os significados dos diversos viveres construídos no espaço. Ele espelha os obstáculos apresentados pelo manguezal, todavia também demonstra saídas possíveis. Reforçando tal possibilidade, este e tantos outros decifram, codificam, produzem e reproduzem seus sentimentos, bem como os de outras pessoas. Enfim, por meio das inúmeras narrativas, legitimam formas de se fazerem enquanto sujeitos constituidores da História. Essa lógica parece ao historiador absolutamente adequada, no entanto, pretende-se chegar um pouco mais além. Os depoimentos que giram em torno das formas de sobrevivência e, logicamente, frente a outras temáticas, são posicionados em inumeráveis instantes e lugares da vida dos narradores, porquanto os agentes que produzem tais discursos sempre estão atentos ao que dizem, para quem dizem e como dizem e, dessa forma, articulam mensagens "passadas" com expectativas do "presente" e vice-versa e, consequentemente, proporcionam continuidades, rupturas, reformulaçôes, reconstruçóes das experiências vividas, sendo que a transversalidade liga dialeticamente os tempos históricos em suas vidas. Destarte, os coletores são sobretudo, homens em ação, visto que fazem constantemente referências à geografia que mais conhecem e assim proporcionam formas de linguagem que buscam legitimar os seus movimentos enquanto sujeitos históricos. Isso acontece porque eles atribuem profundo valor ao vivido, por exemplo, quando expressam os significados da alimentação, do cansaço, dos perigos ao se transitar no manguezal e, paralelamente, suas estratégias frente às diferentes situaçóes. Eles constroem ordens, ou melhor, compóem sentidos para suas atividades cotidianas.

Dito isso, há efetivamente no bojo do ecossistema costeiro em análise um passeio formidável, uma mistura infinita de concepçóes de vida, de costumes e de linguagens que lá transitam cotidianamente. Eis escalonadas não as razões, mas, sim, somente algumas delas, que fazem do manguezal um espaço múltiplo, onde se deslocam não apenas pessoas, mas ideias uma vez que existem inter-relaçóes quando se pensam a captura e a venda do crustáceo e as trocas de concepçóes e de lógicas de sobrevivência. Esses meios são importantes, pois as personagens interpretadas elaboram no ecossistema códigos próprios de relação, de convivência; no trânsito na natureza, os trabalhadores formam trilhas e mesmo caminhos maiores que são utilizados como meios que demarcam campos de sobrevivência para não se perderem 
no interior do ecossistema. Esses movimentos, sejam individuais, sejam em grupos, significam a vida, ou melhor, são eles que orquestram a dialética no seio deste difícil mundo. Enfim, são as dinâmicas socioculturais na nature$z a$, no cotidiano e na disciplina que ora se apresentam. Ainda que se queira, nunca será possível esvaziar os espíritos humanos lá manifestos, porquanto eles possuem preocupaçóes, respostas, soluçóes absolutamente habituais, as quais saem da experiência de cada um no decorrer da vida. Essa vertente é claramente apreciável para aqueles que, retrospectivamente, têm a possibilidade de interrogá-los, pois a respeito das suas "origens", nem sempre são encontradas no seio do ecossistema, todavia, elas se confundem com este, porque se conseguiram respostas que deixaram pasmo o pesquisador, por exemplo, quando disse Seu Manoel: "o mangue é a minha roça". ${ }^{10}$

Volte-se à alimentação como estratégia de sobrevivência e leia-se o raciocínio do Senhor Reinaldo Cunha, 36 anos:

Tem vez que sim, olha, que nem o projeto aí do INCRA, deu muita rede aí pro pessoal não deu pra mim, mais pro zotro deu, aí, às vezes os meninos levam a gente pesca, a gente matando, a gente comi, bacana mermo: tainha é bagre faz um mermo pai dégua, aí pronto, pião, comi chega dá até preguiça de trabalhar. Cozinha, assa de tudo jeito que dê pra comer a gente comi, quando eu tava fazendo essa pesquisa com esse pessoal lá da universidade eles traziam já comida de lá, às vezes eles traziam peixe pra gente assar lá, quando não eles traziam carne frita, a gente entrava às vezes sete e meia, oito horas quando era duas horas a gente saía, aí vinha embora, era tudo marcado no relojinho a hora de sair (...).

As fronteiras e estratégias da sobrevivência significam, relativamente, os mesmos papéis para os homens, entretanto, elas são construídas diversamente. Está tudo aí, a concepção de vida, de cotidiano e de disciplina. Tudo, e nelas encontrar-se-ão hábitos, costumes, tradiçóes, concepções de perigo. Mas, e certamente, acima de tudo a elaboração de experiências. É isso que conta o Senhor Reinaldo, pois o seu cotidiano e de tantos outros está concentrado em normas elementares como as de conseguir o alimento necessário no próprio manguezal ou de levá-lo. Dessas dinâmicas, o que jamais se deve esquecer é que destas mesmas o ponto final desejado localiza-se

10 Entrevista concedida pelo Senhor Manoel Soares da Paixão, 66 anos. Bacuriteua, 24 de maio de 2011. 
no econômico, na captura máxima do crustáceo, no negócio. O ecossistema é fonte de sobrevivência econômica para milhares de pessoas, ele significa lugar de "livre" atividade financeira que, inevitavelmente, reflui na cidade de Bragança, na localidade de Bacuriteua e nas suas adjacências. É por essa razão que o mundo do ecossistema fascina. No entanto, ele (o mundo geográfico onde os homens atuam) em nenhum tempo, pode ser compreendido por alguém que o observe de fora. Assim, para interpretá-lo, deve-se necessariamente adentrá-lo. Essa proposição é necessária, porque os homens nele contidos o movimentam-no, fazendo-o e desfazendo-o. Ele é, sem dúvida, uma obra econômica, mas também política, social, cultural, pois não se deve esquecer que, dele, lutas emanam de todos os ângulos: econômicas, quando se pensam as necessidades dos inumeráveis grupos familiares; políticas, quando nele se localizam as batalhas para sua conservação; sociocultural, ao se analisar as tradiçóes lá contidas como a do famoso Athaíde. ${ }^{11}$

Tudo isso consegue demonstrar, eloquentemente, que os homens que o forjam o ecossistema tem diversas preocupaçóes, contudo, não se deve negligenciar que o lugar é muito misturado, pois naquele quadro geográfico da história pululam homens múltiplos, assim como concepçóes de mundo e de vida variadas, repita-se. Com efeito, é ato imprudente a qualquer pesquisador desenvolver olhar sobranceiro frente aos homens que o dominam ou tentam assim fazer. Com essas ilaçóes, os trabalhadores no seio do manguezal também podem significar relaçóes de força constantes que são exercidas por meio do econômico, do político, do sociocultural e, resolutamente, através de ideias. Assim sendo, como o leitor pode notar deve-se acentuar que há combinaçóes variadas e que elas nem sempre agem ao mesmo tempo e da mesma forma quando a temática concentra-se no que se vem assinalando como dinâmicas socioculturais. Com esse argumento, deve-se compreender que os problemas fundamentais que a natureza impóe vêm sendo dirimidos pelos homens que nele atuam, isto é, os sujeitos sociais - com as suas experiências -, ao se organizarem e se reorganizarem no espaço em que agem, conseguem elaborar modos próprios de sobrevivência no ecossistema. As estratégias forjadas no quadro geográfico em questão podem e devem ser compreendidas como as primeiras afirmaçóes de tudo aquilo que caracteriza, essencialmente, os homens que trabalham naquela geografia.

11 Criatura que ataca sexualmente os homens no interior do manguezal. 
O lugar, isso deve ser assinalado quantas vezes forem necessárias, significa para os trabalhadores o cansaço, a dureza, a dificuldade, mas também é coerente apreender que é a partir do seu interior que vidas se forjam, e isso é perceptível nas almas dos colaboradores (nos interstícios das suas narrativas), pois delas nascem e residem esperanças em melhores dias, sonhos, desejos de conquista, bem como imagens da família imiscuídas no econômico, no político, no social, além das sociabilidades e das solidariedades. Essas características podem ser interpretadas como elos, nexos inquebrantáveis entre homens e natureza, ou melhor, para que não reste dúvida, o que aqueles urdiram sobre esta. Do mesmo modo, da equação, o que é de suma importância reter e que também orienta os argumentos apresentados, é que o ecossistema, não enquanto campo natural, mas sim ao representar o econômico, o social, o político, o cultural, é forjado pelo homem, pois este é o seu personagem ordenador e soberano. Ora, o que se vem afirmando sobre os laços existentes entre homens e natureza, é preciso reafirmar, todavia em termos diferentes. Onde se deseja efetivamente chegar com esse jogo? É necessário, prezado leitor, exercitar um pouco mais a prática da paciência. Apenas com mais uma olhadela compreende-se por que os homens, paulatinamente, dominam e mandam no lugar ou, em outras palavras, tudo aquilo que distingue e caracteriza as seçóes de dificuldades no bojo do ecossistema foram sucessivamente superadas pelos agentes centrais deste ensaio, porquanto eles equacionam a disciplina exigida no bojo do seu cotidiano.

A respeito de alimentação, vestimentas e tempo de labuta, que neste ensaio foram apresentadas como tríade essencial à sobrevivência, apenas mais algumas palavras que, dessa forma, apoiam-se nas narrativas do Senhor Manoel Soares da Paixáo, 66 anos e 50 de experiência como coletor, casado. Quanto à alimentação, leia-se o excerto:

Nós leva feito, tem muito que leva peixe assado, leva carne assada, qualquer comida que ele queira, antão a conserva a sardinha, ou conserva carne mesmo, isso é que é alimentação, no entrar lá pra dentro, como você tá falando, tudo é na beira, quando é aqui que vai ficando na beira da estrada tem que fazer a refeição lá sentado na beira da estrada e as coisas fica todinho ali, como agora que só na fieira e amarrado todinho aqui na cinta, a fieira todinha é amarrada, aí ajeita todinha, faz seu cigarro, merenda aí só come quando vem de novo se deixar se náo deixar ele pode trazer caranguejo, faz 
um fogo na estrada e come e é assim o negócio, é que eu trabalhei muito aí na estrada. E água no manguezal para beber? Leva cada um leva a sua garrafa de água, também só bebe ali na beira da estrada e ficou lá, só bebe água na hora que vem de lá é que chega aí na estrada é que vai tomar água vai comer, é assim (...) É isso mesmo, quando ele toma a água só naquela hora e se manda pra lá, é, tem vez que é longe passando dessa estrada na beira da ponte grande tem a ilha do Bonifácio, uma ilha que tem até gado, a gente faz as merendas muitas vezes o apelido lá da onde a gente tira, é lonjāo, é longe é longe é muito longe, entra na fazenda e anda aí no meio dessa fazenda e vai embora até no fim da fazenda, é muito grande o campo, aí deixa o campo e segue pra dentro do manguezal, pela estrada mesmo, de tanto a gente pisar que fica a estrada e vai embora, tirar caranguejo muito longe sem beber água sem nada até de tarde, é uma hora caboco se manda de lá.

Acerca da vestimenta, afirmou:

Ah, porque estava experimentando de todo o jeito, né, porque nós nu quando tirava até pela barriga pegava o repeláo de pau de raiz de tudo, sem os sapatos o pé vivia cortado furado, é porque o bico da seribeira tem umas que são mole, mas tem umas que se não pode sentar seu pezinho que bateu furou. É bico da seribeira, aí o caboco inventou o sapato, agora até pra tirar pra comer por aí caboco se não meter o sapato e a luva não vai lá. Eu achei foi muito bom, agora pega mais a assuesdade, né, por que uma roupa o dia inteiro molhada, tem uma que dá o meião aqui ainda, passando o dia inteiro aqui na lama molhado, por isso eu a pele da minha barriga é friazinha, tem vez que dói mesmo, quando é seis horas da tarde tou sentado aí, tou sem ter camisa que o vento bate dói. Dói mesmo friadagem na pele da minha barriga.

Sobre o tempo de trabalho no ecossistema, disse:

Ah, nós entrava negócio de sete horas dia aqui na estrada, quando tava duas horas da tarde nós saía fora, apanhava o carro e saía, e por aqui em canoa entrava sete horas saía quatro horas da tarde é quatro hora da tarde caboco.

Na introdução e, em certa medida, no corpo deste texto, esclareceram-se os sentidos da multiplicidade do viver da e na natureza. Dessa forma, neste 
momento, se quer reforçar a ideia de que a alimentação, as vestimentas e o tempo de labuta expressam apenas três aspectos das inumeráveis estratégias presentes no seio do manguezal. Neste artigo não se interpretaram, por exemplo, as funçóes do fumo e da bebida alcoólica. Todavia, deixar-se-ão os subterfúgios de lado e dedicar-nos-emos, imediatamente, ao que mais interessa: as dinâmicas socioculturais elaboradas pelos homens da natureza. Seu Manoel Soares da Paixão precisa claramente o que vem a ser essa dinâmica, porquanto ele nunca fala à revelia, pois sempre esteve conectado às exigências impostas pelo momento histórico vivido. Assim, os homens se revelam ao manguezal buscando dominá-lo e têm - na medida do possível - sucesso na empreitada. No quadro do tempo e, por conseguinte, das vicissitudes do ecossistema eles conseguem forjar ferramentas que os habilitam à sobrevivência nas complicadas condiçóes que enfrentam, logo, é de fundamental importância e, diga-se essencial, compreender esses sujeitos sociais no seio dos grupos de que fazem parte. Tais grupos foram, inquestionavelmente, criados por eles, ou melhor, por meio das suas atividades/práticas cotidianas.

Ao se realizar elementar exame de consciência de uma parte do rico ambiente em questão, chegou-se, não a uma definição, pois a História não é dada a definiçóes, mas, sim, a uma sólida, crê-se, possibilidade interpretativa, qual seja: no que respeita às dinâmicas socioculturais que os homens urdem na natureza, as suas táticas, costumes e hábitos de sobrevivência foram fabricaçóes móveis e nunca - no decorrer do tempo - cristalizaçóes. Houve deslocamentos: quando coletavam o crustáceo absolutamente despidos e, agora, com vestimentas. Esta e tantas outras açóes caracterizam a existência de dinâmicas internas, de significados que estão longe de se constituir em simplórios para os trabalhadores da natureza, para suas famílias, a economia, a política, os costumes, os hábitos locais. Assim, o pesquisador posiciona-se e esteve equidistante de encorajar a lógica de descrever o que se pôde ver mas sim tentou aproximar-se da concepção de ver o que é de suma importância interpretar. Esses campos desejaram-se demonstrar a todo instante. Os depoimentos jamais foram lidos em si, contudo e, fundamentalmente, enquanto narrativas de vidas pautadas em experiências cotidianas, as quais envolvem número amplo de pessoas para além das relaçóes no seio do manguezal (filhos, esposas, parentes próximos e distantes, amigos).

Para finalizar estas reflexóes, é importante localizar que da categoria dinâmicas socioculturais na natureza emanam diversas reflexóes - tais como 
a relação estabelecida entre coletor e marreteiro e as dificuldades para se sustentar uma família - que não puderam ser tratadas neste ensaio, porque nele há um argumento e também em virtude dos limites solicitados ao artigo. Exigem-se a essas empreitadas e a outros pormenores uma obra e, mesmo assim, logicamente, não se esgotariam os significados socioculturais que os homens perfilam no bojo do ecossistema costeiro. Então, nas interpretaçóes ora apresentadas, existem desígnios e eles, aqui, sempre se concentraram no cotidiano, na disciplina, nos hábitos, nos costumes, enfim, nas representaçóes urdidas pelas pessoas interpretadas. Considera-se a presente lógica prudente e assim se leu o manguezal, como necessidades dos homens. Necessidade que cada homem sentiu de que cada grupo humano necessitou, em cada momento da existência, das próprias necessidades a eles inerentes. Com efeito, cada pessoa procura valorizar - evidentemente ao seu modo - os ganhos proporcionados pelo trabalho no seio da natureza e esse campo ajuda os sujeitos sociais a viverem dela. E acrescenta-se: a teoria (dinâmicas socioculturais) dedicou esforços na interpretação da mentalidade dos homens da natureza, isto é, como os trabalhadores organizam em suas cabeças formas, táticas, hábitos, costumes apreendidos como coerentes para se "vencer" as vicissitudes no seio do manguezal do Nordeste paraense. Essa é a seiva das suas vidas. Eles jamais se interpretam como sujeitos sociais fora do mundo que, dia após dia, ajudam a construir. Com efeito, compreendem que o trabalho no ecossistema é duro, cansativo, perigoso, todavia apresentam saídas para as dificuldades surgidas.

\section{Considerações finais}

De tudo o que foi dito, o que é trivial reter concentra-se na ideia de que os homens releem a natureza em questáo com o afấ de dominá-la. É dessa maneira, muito embora náo apenas dessa maneira, que o pesquisador compreende a construçáo do conhecimento histórico. Dito de outra forma, o que se vem categorizando enquanto dinâmicas socioculturais na natureza deve ser analisado como uma casa onde sempre as portas estaráo abertas a visitaçóes contrárias. Assim sendo, desejou-se situar as coisas em seu lugar, todavia elas jamais podem ser interpretadas como estruturas ou cristalizaçóes. 
Também se deve argumentar que as estratégias de sobrevivência, logo o que se chamou de dinâmicas socioculturais, concentraram-se na dieta dos trabalhadores, nos seus instrumentos e no seu tempo de labuta, todavia, reafirme-se, não são as únicas encontradas no seio do ecossistema em pauta.

Neste ensaio, no desejo de se elaborar conhecimento histórico, realizou-se, crê-se, esforços no sentido de se compreender como se situa uma parte do quadro geográfico do ecossistema costeiro do Nordeste do Pará. Os esforços, enfatize-se, justificam-se porque se quis colocar aqueles homens "ditos comuns" na historiografia.

Assim sendo, forças foram concentradas na tese de que há no manguezal dinâmicas socioculturais quando o assunto localiza-se nas estratégias de sobrevivência, e estas sempre estiveram alojadas em determinados aspectos como no da dieta, no dos equipamentos de trabalho, no do controle do tempo de labuta. Repisa-se: este ensaio reuniu esforços no argumento de que há ordem para sobreviver no e do ecossistema. Então, esteve-se atento às formas como os homens daquele rico lugar pensam, compreendem, interpretam o espaço que tão bem conhecem. Ora, eis o que, inspirado nos documentos, se procurou realizar, ou melhor, demonstrar que quem transforma a atmosfera do múltiplo quadro geográfico apresentado são os homens em constante deslocamento, porquanto eles são os atores centrais das problematizaçóes lançadas e foram interpretados em seu próprio fazer-se ou enquanto trabalhadores que estáo atentos às exigências que o lugar lhes apresenta, bem como são agentes sempre dispostos a reler estratégias e por isso pessoas que propóem saídas para as dificuldades surgidas.

$\mathrm{O}$ imenso quadro geográfico onde os mais diversos homens atuam pode ser interpretado como um caleidoscópio de culturas. Em conformidade com isso, em virtude das estratégias urdidas, eles pretendem soçobrar frente às vicissitudes da natureza e, para conseguirem esse afâ, agarram-se em redes de sociabilidades bem cerradas, por eles constituídas, e por isso tal fato proporciona esgueirarem-se das adversidades apresentadas no bojo do ecossistema. De tal monta, as estratégias de sobrevivência na natureza são grandes cadeias de culturas fabricadas por homens. São eles que, sem descansar, forjam e repetem esse processo insistentemente na ânsia de conferir clareza e regularidade ao que fazem. Assim sendo, deve-se observar que esses personagens sociais podem ser lidos um conjunto que se encontra em perpétuo deslocamento, o qual se entrechoca e se mistura elaborando de- 
sempenho absolutamente múltiplo nos lugares em que atua. Dessa maneira, é nesse campo que dinâmicas socioculturais elaboram-se, e compreender o referido domínio foi a finalidade a que este estudo se propôs.

Deve-se, enfim, para abreviar os eflúvios culturais, sociais, econômicos, políticos que emanam do ecossistema costeiro, anotar que há entre eles combinaçóes prodigiosamente sutis e importantes, visto que os homens que nele atuam conseguem agrupar e reforçar, de parte a parte, as devoçóes em torno das suas necessidades e apreensóes. Com efeito, tente-se resolver somente a seguinte equação: o homem atuando no bojo do manguezal, o que pode significar? Ricas combinaçóes, sim, importância para a História, também. Dissociáveis, não. Eis a engrenagem de toda a argumentação ora apresentada.

\section{Documentos}

Entrevista concedida pelo Senhor André Tavares da Gama, 57 anos. Bacuriteua, 12 de maio de 2010.

Entrevista concedida pelo Senhor Pedro Paulo Farias do Rosário, 52 anos. Bacuriteua, 19 de maio de 2010.

Entrevista concedida pelo Senhor Benedito Faustino da Silva, 47 anos. Bacuriteua, 24 maio de 2010.

Entrevista concedida pelo Senhor Miguel Pinheiro da Silva, 67 anos. Bacuriteua, 08 de junho de 2010.

Entrevista concedida pelo Senhor Reinaldo Cunha, 36 anos. Bacuriteua, 21 de junho de 2010.

Entrevista concedida pelo Senhor Manoel Soares da Paixão, 66 anos. Bacuriteua, 24 de maio de 2011.

\section{Referências}

ANTONACCI, M. A. Tradiçóes de oralidade, escritura e iconografia na literatura de folhetos: Nordeste do Brasil, 1890/1940. In: PROJETO HISTÓRIA No 22: História e oralidade. 
Revista do Programa de Estudos Pós-Graduados em História da Pontifícia Universidade Católica de São Paulo. Sáo Paulo: EDUC, 2001, p. 105-138.

CAMPOS, I. D. História e natureza: memórias, sobrevivências, famílias e relações de poder no manguezal (Bragança - PA, 1980 a 1990). Artigo aprovado pela Revista Margens, Campus de Abaetetuba da Universidade Federal do Pará (UFPA), 2010.

KHOURY, Y. A.. Narrativas orais na investigação da história social. In: PROJETO HISTÓRIA No 22: História e oralidade. Revista do Programa de Estudos Pós-Graduados em História da Pontifícia Universidade Católica de São Paulo. São Paulo: EDUC, 2001, p. 79-103.

PORTELLI, A. O que faz a história oral diferente. In: PROJETO HISTÓRIA No 14: Cultura e representação. Revista do Programa de Estudos Pós-Graduados em História da Pontifícia Universidade Católica de São Paulo. São Paulo: EDUC, 1997, p. 25-39.

THOMPSON, E. A miséria da teoria ou um planetário de erros. S/C: Swing e Ludistas Sensuais, 2009.

Resumo: $\mathrm{O}$ caráter dos argumentos que seguem é o de demonstrar como pessoas ditas "comuns", que labutam diariamente no bojo de uma parte do ecossistema costeiro paraense (Bacuriteua Bragança PA) constituem história e como que esta pode figurar na historiografia por meio da análise das suas experiências no seio do manguezal. Porém, deve-se, para esse propósito, acentuar que as diversas dinâmicas serão explicadas por meio da categoria, aqui intitulada de dinâmicas socioculturais e, por isso, o enfoque concentrou-se nas formas de sobrevivência forjadas pelos trabalhadores da natureza no interior do quadro geográfico em análise.

Palavras-chave: natureza, cotidiano, coletores.

Daily in the growth of mangroves: collectors and survival strategies in the nature, Bacuriteua-Pará (1975-1990)

\begin{abstract}
The character of the arguments that they proceed is it of demonstrating as "common" said people that they labor daily in the salience of a part of the ecosystem coastal paraense (Bacuriteua Bragança PA) they constitute history and that this can represent in the historiography through the analysis of their experiences in the breast of the growth of mangroves. However, he/she is due, to this purpose to accentuate that the several dynamics will be explained through the category, here, entitled of partner-cultural dynamics and, for that, the focus concentrated on the wrought survival forms for the workers of the nature inside the geographical picture in analysis.
\end{abstract}

Keywords: nature, daily, collectors.

Recebido em: 16/03/2012

Aprovado em: 17/06/2012 